\title{
PENGEMBANGAN MODEL TEACHING FACTORY DI BENGKEL OTOMOTIF SMK KARSA MULYA PALANGKA RAYA
}

\author{
Galfri Siswandi ${ }^{1}$ dan Sukoco ${ }^{2}$ \\ ${ }^{1}$ Pendidikan Teknik Mesin Universitas Palangkaraya; ${ }^{2}$ Fakultas Teknik Universitas Negeri Yogyakarta \\ E-mail: galfri_siswandi@yahoo.com
}

\begin{abstract}
The objective of the study is to develop an applicable Teaching factory model for practices in the automotive workshop of SMK Karsa Mulya Palangkaraya. This study used a quantitative approach. It was conducted in grade XI of Motorcycles Engineering Department at SMK Karsa Mulya Palangkaraya. It was carried out in five phases: (1) preliminary investigation, (2) design; (3) realization / construction, (4) test, evaluation and revision, (5) field testing / implementation. Data collection instruments consisted of observation sheets and assessment sheets. The results of the competency tests of 19 students were: (a) Tune Up; the highest score, the lowest score and the average score were 98.82, 89.41, 95.23 respectively (b) Over Haul; the highest score, the lowest score and the average score were 90.67, 82.67, 85.55 respectively (c) System Starter; the highest score, the lowest score and the average score were 80.00, 77.33, 78.00 respectively. Thus it was noted that the model can be applied in the vocational workshop of Motorcycle Engineering Department at SMK Karsa Mulya Palangkaraya.
\end{abstract}

Keywords: Automotive Workshop, Practices, Teaching factory

\begin{abstract}
ABSTRAK
Penelitian ini bertujuan untuk mengembangkan model Teaching factory pada pembelajaran praktik di bengkel Otomotif yang sesuai di SMK Karsa Mulya Palangka Raya. Penelitian ini menggunakan pendekatan kuantitatif yang dilakukan terhadap siswa kelas XI jurusan Teknik Sepeda Motor SMK Karsa Mulya Palangka Raya. Penelitian ini dilakukan melalui lima fase yaitu: (1) investigasi awal, (2) desain; (3) relisasi/kontruksi, (4) tes, evaluasi dan revisi, (5) uji lapangan/implementasi. Instrumen pengumpulan data terdiri atas lembar observasi persiapan, lembar observasi proses, dan lembar penilaian hasil ujian praktik siswa. Hasil uji kompetensi terhadap 19 orang siswa yaitu: (a) Tune Up nilai tertinggi $(98,82)$, nilai terendah $(89,41)$ dan nilai rata-rata $(95,23)$, (b) Over Haul nilai tertinggi $(90,67)$, nilai terendah $(82,67)$ dan nilai rata-rata $(85,55)$, (c) Sistem Starter nilai tertinggi $(80,00)$, nilai terendah $(77,33)$ dan nilai rata-rata $(78,00)$. Dengan demikian jelas bahwa model teaching factory dapat digunakan dan diterapkan pada bengkel Kejuruan jurusan Teknik Sepeda Motor SMK Karsa Mulya Palangka Raya.
\end{abstract}

Kata kunci: Bengkel Otomotif, Pembelajaran Praktik, Teaching factory

\section{PENDAHULUAN}

Pengertian pendidikan kejuruan dikembangkan dari terjemahan konsep vocational education dan occupational education, keduanya termasuk dalam pendidikan untuk menghasilkan teknisi industri. Secara historis sekolah kejuruan merupakan pengembangan dari pelatihan kerja. Dalam pelatihan kerja, peserta didik dapat belajar sambil bekerja. Direktorat PSMK (2006) menyatakan bahwa Sekolah Menengah Kejuruan (SMK) merupakan lembaga pendidikan yang berperan untuk menyiapkan peserta didik menjadi tenaga kerja tingkat menengah untuk membantu pembangunan sektor pereko- nomian bangsa. Pendidikan kejuruan berorientasi lebih dekat dengan persyaratan sistem kerja dan pasar tenaga kerja yang sesuai kebutuhan industri. Pendidikan kejuruan sangat penting di negara-negara berkembang karena pendidikan kejuruan dapat melatih siswa secara terampil untuk menguasai teknologi yang baru. Hal ini didasari karena perkembangan teknologi dapat memberikan kontribusi yang besar bagi perkembangan suatu Negara.

Pendidikan kejuruan merupakan sebuah lembaga pendidikan yang berupaya memberikan pengalaman baik afektif, kognitif dan psikomotorik dalam rangka persiapan siswa memasuki dunia kerja dan untuk menunjang se- 
seorang dalam menjalani kariernya di dunia kerja. Clarke dan Winch (2007) menyatakan bahwa pendidikan kejuruan merupakan upaya pengembangan sosial ketenagakerjaan, pemeliharaan, percepatan, dan peningkatan kualitas tenaga kerja tertentu dalam rangka peningkatan produktifitas masyarakat. Pembelajaran adalah suatu proses penyampaian pengetahuan yang dilaksanakan dengan menggunakan sebuah metode. Rumusan tersebut sejalan dengan pendapat Mc. Donald (Hamalik, 2007) yang memaparkan bahwa pendidikan adalah suatu proses atau kegiatan yang bertujuan menghasilkan perubahan tingkah laku manusia. Selanjutnya proses belajar menghasilkan perilaku yang dikehendaki dan merupakan hasil dari pembelajaran. Berdasarkan konsep di atas maka dapat disimpulkan bahwa pendidikan kejuruan merupakan sebuah lembaga pendidikan yang memiliki tujuan mendidik dan menciptakan SDM yang mempunyai kemapuan baik dalam bidang afektif, kognitif dan psikomotor sehingga siap terjun ke dunia kerja dengan tingkat kompetensi yang baik.

Bengkel merupakan salah satu sarana dari pendidikan teknik dan kejuruan yang berfungsi sebagai tempat melatih dan mengembangkan keterampilan psikomotorik seseorang yang akan mendalami suatu keterampilan tertentu. Menurut asal mulanya bengkel otomotif termasuk dalam salah satu kategori laboratorium, bahkan ada yang menyebutkan laboratorium juga disebut dengan sebutan bengkel (Their, 1970). Pendidikan kejuruan memerlukan peralatan yang spesifik untuk tiap jenis bidang kejuruan, karena program keterampilan kejuruan akan berhasil dan memuaskan jika disediakan peralatan praktik yang layak, karena kompetensi yang menyangkut ranah keterampilan tidak akan sukses hanya dengan pembelajaran teori saja (Storm, 1995). Hal tesebut memberi arti bahwa untuk menanamkan suatu kompetensi, siswa harus dididik mendekati kondisi nyata atau lingkungan sebenarnya seperti di tempat kerja, sehingga bengkel beserta isinya harus benarbenar memenuhi untuk melakukan pembelajaran praktik.
Persyaratan pokok bengkel yang harus diperhatikan dan dilaksanakan sebagai ciri utama yaitu adanya, temperatur lingkungan kerja baik sesuai dengan kaidah persyaratanya, pencahayaan yang baik, dan hemat energi, tingkat kebisingan rendah, warna yang sesuai dan tidak menimbulkan refleksi yang merusak kesehatan mata, kelengkapan perangkat untuk keselamatan kerja, dan tata letak bengkel yang ideal (school shop and the education Digest, 1982). Terdapat lima syarat yang harus dipertimbangkan dalam penyimpanan perlengkapan, alat, dan peralatan bengkel otomotif menurut Edward dan Andrew (1976), yaitu: (1) safekeeping (penyimpanan); (2) accessibility (mudah dijangkau); (3) ease of handling (mudah dalam penanganan); (4) inventorying (pengimpentarisan); dan (5) safety (keamanan). Berdasarkan kelima syarat tersebut diharapkan dalam proses pelaksanaan praktik akan jauh lebih mudah dan terlihat rapi serta aman.

Salah satu fungsi bengkel adalah sebagai sarana praktikum belajar. Belajar adalah proses perubahan tingkah laku individu sebagai hasil interaksi. Orlich et.al (2007) menjelaskan bahwa berdasarkan perspektif tingkah laku, belajar dapat digambarkan sebagai suatu perubahan tingkah laku yang dapat diamati. Bengkel merupakan tempat pelaksanaan pembelajaran praktik. Pembelajaran praktik kejuruan merupakan ciri khas dari proses pembelajaran selain pembelajaran teori. Orlich et.al (2007) menyatakan bahwa domain kognitif mencakup sasaran atau hasil yang berhubungan dengan daya ingat, pengenalan pengetahuan, pengembangan kemampuan intelektual dan keterampilan. Seseorang tidak dapat menguasai teori dengan baik tanpa praktik, sebaliknya seseorang tidak dapat melaksanakan praktik dengan efektif tanpa pemahaman teori yang baik. Sejalan dengan pendapat Finch \& Crunkilton (1999), yang menyatakan bahwa belajar dalam pengembangan kepribadian tidak hanya terbatas di dalam kelas atau laboratorium, siswa dapat mengembangkan keterampilan dan kemampuanya melalui berbagai aktivitas pembelajaran dan pengalaman yang tidak memerlukan hitungan 
kredit seperti halnya lulusan dari lembaga pendidikan. Hal tersebut semakin menegaskan bahwa bengkel merupakan tempat yang tepat sebagai tempat pembelajaran praktik.

Fungsi lain dari bengkel adalah sebagai unit produksi sekolah. Secara umum unit produksi sekolah merupakan suatu program yang pada awalnya merupakan satu kesatuan dengan program pengembangan sekolah seutuhnya dalam program pengembangan sekolah (school integrated development). Unit produksi merupakan proses kegiatan usaha yang dilakukan disekolah dan bersifat bisnis yang diharapkan dapat mendatangkan keuntungan ganda (finansial maupun nonfinansial). Unit produksi merupakan suatu aktivitas bisnis yang dilakukan oleh warga sekolah secara berkesinambungan dalam mengelola sumber daya sekolah yang dimiliki serta dikelola secara profesional sehingga dapat menghasilkan barang atau jasa yang mendatangkan keuntungan.

Berdasarkan teori mengenai bengkel otomotif di atas dapat disimpulkan bahwa bengkel otomotif merupakan sebuah tempat yang dipergunakan oleh pihak sekolah kejuruan dalam menjalankan proses pembelajaran praktik, bengkel otomotif juga berfungsi sebagai unit produksi sekolah. Dalam pencapaiaan tujuan sekolah terkait program di bengkel, maka sebuah bengkel harus memiliki beberapa ketentuan. Ketentuan tersebut berupa standar kompetensi pengelola, standar laboran, standar kompetensi yang diajarkan di sekolah dan disesuaikan dengan kompetensi yang dibutuhkan dunia industri. Dengan demikian diperlukan suatu model pembelajaran di bengkel yang dapat dilakukan untuk mengoptimalkan pembelajaran praktik dan unit produksi. Pengertian model yang digunakan dalam konteks ini adalah pola (contoh, acuan, ragam) dari sesuatu yang akan dibuat artinya semua sesuatu yang mewakili atau menggambarkan yang dicontoh. Forester (1973), mendefinisikan bahwa model sebagai pengganti dari suatu benda atau suatu sistem yang sebenarnya, yang dilakukan untuk keperluan penyelidikan suatu eksperimen.
Pendidikan Sistem Ganda (PSG) merupakan salah model pendidikan yang selama ini banyak digunakan dan dikembangkan di SMK seluruh Indonesia. PSG pada dasarnya merupakan suatu bentuk penyelenggaraan pendidikan kejuruan yang memadukan secara sinkron program pendidikan di sekolah dan program pengusaan keahlian yang diperoleh melalui kegiatan bekerja langsung di dunia kerja untuk mencapai suatu tingkat keahlian profesional tertentu. Dengan demikian, PSG merupakan suatu strategi yang mendekatkan peserta didik ke dunia kerja. Kendala yang dihadapi dalam program pelaksanaan PSG terdapat pada dua pihak yaitu pada pihak sekolah dan pada pihak industri (Dikmenjur, 1996). Kendala yang terjadi oleh pihak sekolah yaitu: (1) keragaman geografis; (2) keragaman kesiapan dan tingkat kemajuan SMK; (3) keragaman program SMK yang belum seimbang dengan keragaman industri disekitar. Sugihartono (2009), kendala yang dihadapi oleh pihak industri yaitu: (1) belum dimiliki struktur jabatan dan keahlian yang mantap terutama pada industri kecil, dan menengah; (2) belum ada perencanaan alokasi biaya untuk pengembangan pendidikan; (3) belum memiliki persepsi tentang keuntungan PSG bagi industri; dan (4) kuranganya kesadaran tentang peningkatan keefektifan efisiensi, dan kualitas dalam pelaksanaan pelatihan di industri.

Teaching factory merupakan suatu konsep yang menggabungkan belajar dan lingkungan kerja yang realistis dan untuk memunculkan pengalaman belajar yang relevan (Nayang Polytechnic, 2003). Pembelajaran ini merupakan proses praktik yang mengintegrasikan aplikasi berorientasikan pelatihan dengan pendekatan pemecahan masalah. Alptekin et al. (2001), memaparkan bahwa teaching factory memiliki tujuan ganda. Salah satunya adalah untuk memungkinkan siswa untuk mengembangkan skala kecil produk industri atau barang konsumsi. Pembangunan melibatkan membuat prototype dan konsep dasar dari teaching factory dan kemajuan sampai saat ini disajikan sebagai berikut bagian informasi lebih lanjut tentang berbagai proyek yang sedang berlangsung dapat 
ditemukan di teaching factory pengembangan website. Lamancusa et al. (2008), mengemukakan bahwa konsep teaching factory ditemukan karena tiga hal yaitu: (1) pembelajaran yang biasa saja tidak cukup; (2) keuntungan peserta didik diperoleh dari pengalaman praktik secara langsung; dan (3) pengalaman pembelajaran berbasis team yang melibatkan siswa, staf pengajar dan partisifasi industri memperkaya proses pendidikan dan memberikan manfaat yang nyata bagi semua pihak. Dengan demikian dapat disimpulkan bahwa teaching factory adalah kegiatan pembelajaran dimana siswa secara langsung melakukan kegiatan produksi baik berupa barang atau jasa di dalam lingkungan pendidikan sekolah.

Hadlock et al. (2008), menjelaskan bahwa tujuan teaching factory adalah menyadarkan bahwa mengajar siswa seharusnya lebih dari sekedar apa yang terdapat dalam buku. Peserta didik tidak hanya mempraktikan soft skill dalam pembelajaran, belajar untuk dapat bekerja secara tim, melatih kemampuan komunikasi secara interpersonal, tetapi mendapatkan pengalaman secara langsung dan latihan bekerja untuk memasuki dunia kerja nantinya. Pembelajaran teaching factory mengajarkan kepada siswa bagaimana menemukan masalah, membangun prototype, belajar membuat proposal bisnis, dan belajar untuk mempresentasikan solusi yang mereka miliki. Proses pembelajaran teaching factory peserta didik belajar tentang keterampilan yang penting untuk dikuasai, seperti bagaimana cara untuk memenuhi tingkat waktu dan dugaan-dugaan yang mungkin muncul, membangun dan bekerja dalam tim serta bekerja sama dengan beragam orang yang memiliki kemampuan dan bakat yang beragam.

Program teaching factory dapat berjalan jika sarana dan prasarana yang dimiliki oleh sekolah memenuhi standar untuk melakukan kegiatan produksi baik berupa barang atau jasa sesuai dengan program pendidikan yang dimilikinya. Dalam indikator SMK RSBI yang dikeluarkan oleh Direktorat PSMK (2008), kriteria fasilitas yang harus dimiliki SMK adalah fasilitas standar training workshop, advance training workshop dan teaching factory. Fasilitas yang dimiliki dalam standar training workshop adalah standar minimal yang harus dimiliki agar terlaksananya kegiatan pembelajaran sesuai dengan kurikulum sedangkan advance training workshop merupakan tempat untuk melakukan kegiatan pembelajaran, sedangkan teaching factory merupakan fasilitas yang dikhususkan untuk kegiatan produksi yang berupa barang dan jasa.

Siswanto (2011), menyatakan bahwa proses teaching factory yang telah dilaksanakan di SMK RSBI di daerah Yogyakarta dipengaruhi faktor pendukung dan penghambat. Faktor pendukung pelaksanaan teaching factory ialah: (1) fasilitas peralatan yang baik; (2) sumber daya manusia; (3) produk yang dihasilkan; (4) pengaruh pasar; (5) kepemimpinan; dan (6) pemasaran. Faktor penghambat pelaksanaan teaching factory ialah: (1) aturan tentang legalitas unit produksi; (2) kurangnya pemasaran; (3) persepsi orang tua siswa; (4) harga dari produsen terlalu tinggi; dan (5) kesibukan guru dan siswa. Hasbullah (2010), menyimpulkan bahwa salah satu pendekatan pembelajaran yang berbasis produksi dan pembelajaran di dunia kerja adalah dengan pabrik pembelajaran atau dikenal dengan teaching factory (TEFA). Penelitian ini adalah pelaksanaan pembelajaran praktik dengan model teaching factory memanfaatkan unit produksi yang dimiliki oleh sekolah sebagai tempat pelaksanaan teaching factory. Sukardi (2008), memaparkan pengembangan model bengkel kerja praktik terpadu di jurusan Teknik Mesin SMK rumpun teknologi dengan mengadopsi konsep teaching factory. Model bengkel kerja praktik tersebut meliputi: (1) pengelolaan bahan praktik; (2) pengelolaan mesin perkakas dan peralatan praktik lainya; (3) sistem perawatan perbaikan mesin perkakas dan peralatan praktik lainya; (4) organisasi penanganan siswa; (5) tenaga pengajar dan teknisi bengkel kerja praktik; (6) pengelolaan keselamatan kerja yang baik; (7) kemanfaatan (use factor) penggunaan mesin perkakas praktik dan peralatan praktik; (8) pola kepemimpinan; dan (9) 
pengelolaan proses pembelajaran di bengkel kerja praktik.

Evaluasi merupakan bidang kegiatan ilmiah yang telah mendapat perhatian cukup besar. Stark dan Thomas (1994), menyatakan bahwa evaluasi merupakan suatu proses atau kegiatan pemilihan, pengumpulan, menganalisis dan penyajian informasi yang sesuai untuk mengetahui sejauhmana tujuan program, prosedur, produk atau strategi telah dijalankan. Sehingga bermanfaat bagi pengambilan keputusan serta dapat menentukan beberapa alternatif keputusan untuk program selanjutnya. Tujuan evaluasi menurut Stufflebeam dan Shinkfield (1985), menyatakan bahwa" The most important purpose of evaluation is not to prove, but to improve”. Kalimat tersebut menjelaskan bahwa tujuan evaluasi adalah untuk meningkatkan, bukan membuktikan. Berdasarkan tujuan dilakukannya evaluasi di atas dapat disimpulkan evaluasi yaitu sebuah proses yang dilakukan untuk memperoleh data informasi yang dibutuhkan dalam mengambil keputusan menyangkut proses maupun produk yang dihasilkan dalam suatu kegiatan. Berkaitan dengan kajian teori tersebut dalam proses pengembangan pembelajaran yang menerapkan teaching factory, evaluasi dilakukan berdasarkan proses pengembangan yang dilakukan dan produk yang dihasilkan. Kemudian hasil dari observasi terhadap proses tersebut dijadikan sebagai sumber data yang kemudian dilakukan analisis apakah model teaching factory sudah cukup efektif dilaksanakan di SMK Karsa Mulya Palangka Raya.

Efektif memiliki arti manjur, dapat membawa hasil atau berhasil guna (Badan Pengembangan dan Pembinaan Bahasa, 1995). Keefektifan berarti kebersihan atau ketepatan menjalankan semua rencana sebuah program. Efektivitas dengan kata dasar efektif merujuk pada rasio antara output terhadap input. Efektivitas merupakan ukuran yang menyatakan sejauh mana sasaran dalam hal ini kuantitas, kualitas, dan waktu yang dicapai. Masalah efektivitas biasanya berkaitan erat dengan perbandingan antara tingkat pencapaiaan tujuan dan rencana yang telah disusun sebelumnya. Usman (1998), mendeskripsikan efektivitas adalah melakukan pekerjaan yang benar (doing the right thing). Usman juga menjelaskan bahwa efektivitas merupakan kemampuan memilih sumber daya dengan alat dan teknologi yang tepat dalam mencapai tujuan yang telah ditetapkan. Berdasarkan beberapa pengertian tentang efektivitas diatas dapat disimpulkan bahwa efektivitas adalah keberhasilan dalam melaksanakan proses serta pencapaian tujuan sesuai dengan rencana yang telah disusun sebelumnya. Terkait dengan penelitian yang akan dilaksanakan jenis efektivitas yang dimaksud yaitu apakah pengembangan model teaching factory di SMK Karsa Mulya palangka Raya dapat dilaksanakan dengan baik. Efektivitas dari pengembangan ini dapat dilihat berdasarkan hasil dari proses pelaksanaan pembelajaran praktik terhadap model yang dikembangkan, dimana siswa diharapkan tidak hanya mampu melakukan praktik sesuai dengan prosedur tetapi siswa mampu menyelesaikan pekerjaan sesuai jam kerja serta mampu menganalisis serta mampu menentukan solusi terhadap masalah yang dihadapi pada saat bekerja/praktik. Dalam artikel ini dipaparkan mengenai pengembangan pembelajaran praktik yang mengadopsi model teaching factory yang dilaksanakan di bengkel Otomotif SMK Karsa Mulya Palangka Raya.

\section{METODE}

Metode yang digunakan dalam penelitian ini adalah Research and Development (R\&D) yang mengadopsi pendekatan sebagaimana dikemukakan oleh Plomp (1997). Pengembangan dilakukan melalui beberapa tahapan,meliputi: (1) investigasi awal; (2) desain; (3) realisasi/ kontruksi; (4) tes, evaluasi dan revisi; dan (5) uji lapangan/implementasi. Diagram alir taha-pan pengembangan digambarkan pada Gambar 1 berikut ini 
Investigasi awal
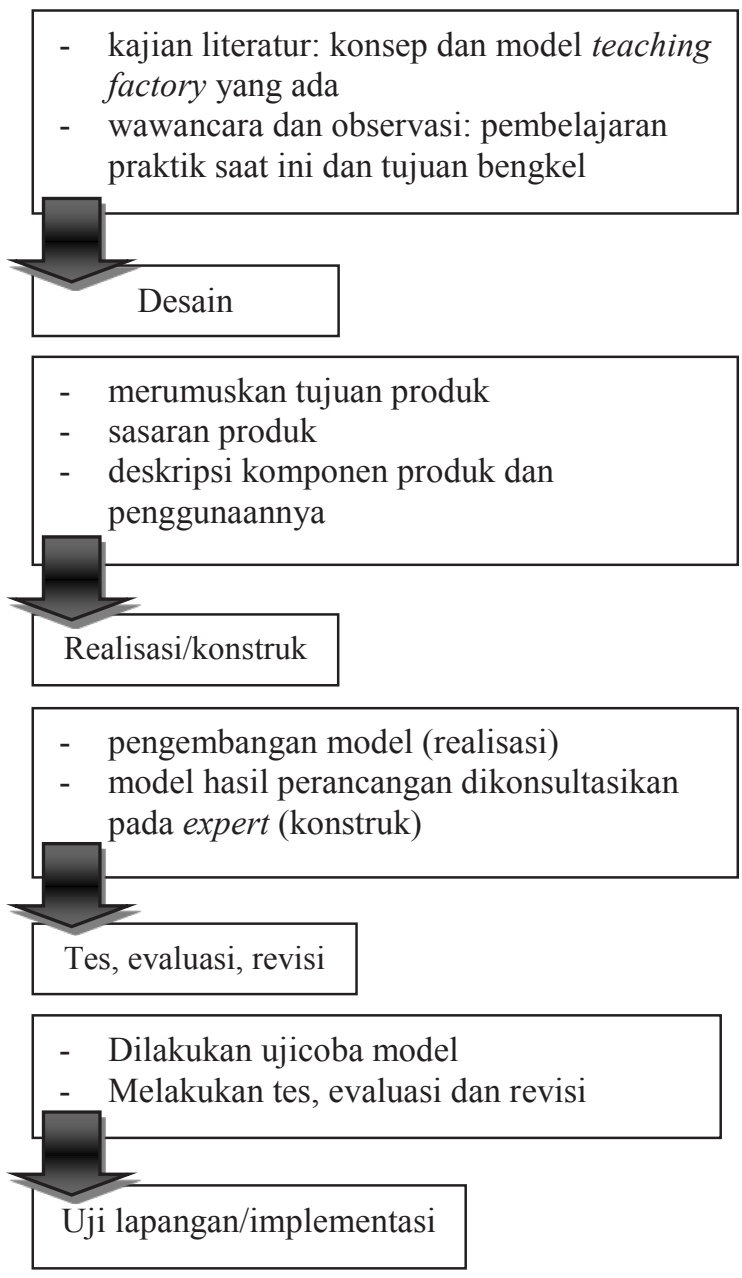

- Observasi langsung proses praktik (validasi tahapan model pembelajaran)

- Analisis hasil praktik siswa setelah melaksanankan pembelajaran praktik dengan model teaching factory

- Dilakukan berulang-ulang hingga hasil memehuhi target

\section{Gambar 1. Tahapan pengembangan}

Dari Gambar 1 diketahui bahwa pada tahapan investigasi awal, dilaksanakan pengumpulan data awal sebagai dasar penentuan model yang akan diterapkan di dalam pengelolaan sarana dan prasarana bengkel otomotif. Penentuan model pengelolaan yang tepat diharapkan akan menghasilkan peningkatan dan efektivitas pemanfaatan sarana dan prasarana bengkel sebagai sarana penunjang dari sebuah proses pembelajaran praktik. Pengumpulan data atau informasi awal melalui kajian literatur, dan observasi terkait dengan sumber data yang perlu diketahui. Berdasarkan data yang diperoleh kemudian dilakukan pengkajian tentang model yang diterapkan sehingga ditemukan model yang dikembangkan di bengkel SMK Karsa Mulya Palangka Raya. Berdasarkan hasil data yang diperoleh dalam tahap investigasi awal (pengumpulan data dan informasi), kemudian dilakukan perancangan model pembelajaran praktik yang cocok di bengkel otomotif SMK Karsa Mulya Palangka Raya. Dalam tahap perancangan ini beberapa hal yang harus dilakukan yaitu: (1) merumuskan tujuan produk; (2) sasaran produk; dan (3) deskripsi komponen produk dan penggunaannya. Tahapan selanjutnya adalah realisasi/konstruksi yang dilaksanakan sekaligus dengan tahapan evaluasi dan revisi. Setelah revisi dilakukan maka selanjutnya dilakukan tahapan uji lapangan/ implementasi sampai dengan hasil sesuai target.

Penelitian ini dilaksanakan di SMK Karsa Mulya Palangka Raya, yang terletak di Jl. G. Obos. KM 4,5 Nomor. 130 Palangka Raya. Subjek penelitian terdiri atas: Kepala Bengkel, Laboran, Instruktur dan siswa otomotif jurusan Tenik Sepeda Motor (TSM). Analisis data observasi langsung dilaksanakan pada saat peneliti berada di lapangan dan dilaksanakan sebagai alat dalam proses pengembangan untuk menentukan model yang akan dikembangkan serta sebagai salah satu strategi yang digunakan untuk memantau keterlaksanaan proses yang dilakukan. Pengumpulan data proses pengembangan dilakukan dengan observasi langsung oleh peneliti, sedangkan untuk data hasil dari proses yang dilakukan yaitu dengan melakukan tes terhadap beberapa kompetensi yang sudah dilakukan pada saat siswa melakukan praktik. Dalam proses analisis data hasil tes ujian praktik siswa dilakukan berdasarkan kriteria yang sudah dibuat kemudian dianalisis secara deskriptif kuantitatif untuk melihat keberhasilan proses model yang dikembangkan. 


\section{HASIL DAN PEMBAHASAN}

Pengembangan model yang dilaksanakan merupakan penerapan model teaching factory di bengkel SMK Karsa Mulya Palangka Raya. Model yang dimaksud adalah sebuah model praktik di bengkel otomotif jurusan Teknik Sepeda Motor yang dirancang berdasarkan konsep teaching factory. Pengembangan model teaching factory tersebut dilaksanakan dengan tujuan meningkatkan proses pengelolaan sarana dan prasarana yang dimiliki serta menerapkan sebuah proses pembelajaran praktik di bengkel sesuai dengan konsep tentang teaching factory. Proses pembentukan model teching factory yang diterapkan dalam penelitian ini diadopsi berdasarkan kajian teori tentang konsep-konsep teaching factory, gambaran bentuk model-model teaching factory yang telah ada, gambaran model praktik yang dimiliki oleh SMK Karsa Mulya Palangka Raya, dan rencana pembangunan bengkel umum milik sekolah yang dikelola oleh sekolah dengan memanfaatkan kompetensi siswa didalam prosesnya.

Gambaran mengenai model teaching factory, yaitu berupa pembelajaran praktik berbasis team yang melibatkan siswa, staf pengajar dan partisipasi industri dengan pendekatan pemecahan masalah yang relevan dengan kebutuhan industri yang berfungsi sebagai latihan bekerja untuk memasuki dunia kerja nantinya (Lamancusa et al., 2008; Nayang Polytecnic, 2003; Alptekin et al., 2001; Hadlock et al, 2008; dan Direktorat PSMK, 2006). Hasil penelaahan mengenai model-model teaching factory yang ada, maka dapat disimpulkan bahwa pelaksanaan pembelajaran praktik dengan model teaching factory dapat dilaksanakan di unit produksi dan memerlukan persiapan tertentu terkait kebutuhan praktik, ruangan belajar, strategi pembelajaran Siswanto (2011), Hasbullah (2010), Sukardi (2008)). Unit produksi di bengkel SMK Karsa Mulya dapat digunakan dalam model teaching factory. Fungsi bengkel selain sebagai unit produksi dapat juga digunakan sebagai tempat belajar praktik (Finch dan Crunkilton, 1999). Berdasarkan konsep yang telah dikemukakan para ahli, gambaran model teaching factory teaching yang telah dilakukan dan fungsi bengkel, selanjutnya disesuaikan dengan kondisi di SMK Karsa Mulya Palangka Raya.

Pengembangan model teaching factory dalam penelitian ini juga dikembangkan berdasarkan hasil prasurvey yang dilakukan di bengkel SMK Karsa Mulya Palangka Raya. Berdasarkan hasil prasurvey tersebut diperoleh gambaran mengenai model praktik yang biasa dilakukan di SMK Karsa Mulya Palangka Raya. Berdasarkan hasil observasi data pendukung persiapan yang dilakukan diperoleh data yaitu: (1) SMK Karsa Mulya sudah memiliki bengkel yang sudah siap digunakan sebagai tempat untuk melaksanakan proses praktikum; (2) unit produksi yang dimiliki oleh sekolah tersedia dalam menunjang jenis pengembangan model teaching factory yang akan dilakukan; (3) kunci-kunci, alat ukur yang dimiliki oleh sekolah telah siap dan memadai untuk melaksanakan proses praktikum, berdasarkan observasi langsung bahwa SMK Karsa Mulya Telah memiliki 4 set toolbox lengkap yang baru dan 4 set toolbox yang lama beserta beberapa alat ukur untuk kejuruan teknik sepeda motor; (4) SMK Karsa Mulya untuk meja kerja (stand lift) belum tersedia sehingga dalam proses praktikum dilaksanakan memanfaatkan luas ruangan bengkel yang disusun sebaik mungkin sehingga proses praktikum bisa dilaksanakan dengan baik dan nyaman, proses tersebut dilaksanakan seperti proses kerja di dunia industri yang juga tidak memiliki stand lift; (5) kompresor berukuran sedang telah tersedia, sehingga untuk proses praktik teknik sepeda motor sudah sangat layak digunakan; (6) bahan praktik merupakan sepeda motor riil tidak lagi dilaksanakan dikarenakan praktik bersifat training object. Bahan praktik tersebut yaitu sepeda motor milik konsumen seperti sepeda motor dewan guru, kepala sekolah, seluruh siswa, dan masyarakat umum yang mengetahui keberadaan bengkel sekolah melalui informasi yang disampaikan oleh seluruh siswa; (7) SMK Karsa Mulya telah memiliki prosedur tentang $\mathrm{K} 3$ seperti adanya tata tertip kerja di bengkel akan tetapi untuk poster- 
poster prosedur K3 masih kurang; (8) manual servis yang digunakan yaitu beberapa buku manual teknik sepeda motor jenis Honda dan yamaha sebagai contoh yaitu manual servis sepeda motor vega; (9) dari segi penataan ruangan yang dilakukan sebelum proses kegiatan praktik dengan konsep teaching factory dilaksanakan maka dilakukan penataan lemari alat dan bahan, ruang tempat tunggu konsumen, ruang kepala bengkel dan guru sehingga proses praktikum bisa berjalan dengan nyaman untuk proses ini telah terlaksana dengan baik; (10) salah satu keunikan yang diterapkan di SMK Karsa Mulya yaitu sekolah atau bengkel dengan menjalankan sistem memberikan kepercayaan penuh pada siswa dengan upaya melatih siswa dalam belajar bertanggung jawab; dan (11) untuk jadwal maintenance alat dan bahan dilaksanakan setiap awal dan akhir semester oleh guru praktik dan instruktur, sedangkan untuk rungan tempat pelaksanaan praktik kebersihan dan kenyamanan lingkungan selalu di jaga setiap hari. Data-data tersebut mendukung proses persiapan dalam model teaching factory. Dengan demikian, dapat disimpulkan bahwa SMK Karsa Mulya Palangka Raya telah memenuhi syarat untuk melaksanakan model pembelajaran praktik teaching factory.

Dari paparan tersebut secara umum model pembelajaran praktik yang dilaksanakan di SMK Karsa Mulya Palangka Raya tersebut murni memanfaatkan bengkel sebagai sarana praktik tanpa melibatkan fungsi bengkel sebagai unit produksi, dalam proses pembelajaran praktik kegiatan persiapan dilaksanakan oleh guru dan instruktur sedangkan siswa hanya berperan dalam pelaksanaan proses pembelajaran saja. Pelaksanaan proses pembelajaran yang dilakukan yaitu menggunakan sistem training object. Dalam proses pembelajaran tersebut terdapat pemisahan antara unit produksi dan pembelajaran praktik. Proses pelaksanaan pembelajaran praktik yang dilaksanakan terdiri atas dua bagian yaitu persiapan dan pelaksanaan pembelajaran. Proses persiapan yaitu: (1) penyediaan bahan praktik yang dilakukan oleh guru; (2) penataan ruangan tidak menjadi sebuah permasalahan karena yang diutamakan adalah terkait siswa dapat praktik dengan baik; dan (3) penetapan strategi pembelajaran yaitu dengan menggunakan sistem training object. Kemudian proses pelaksanaan pembelajaran yaitu: (1) siswa praktik dengan melakukan servis mesin atau objek yang telah dimiliki sekolah; (2) praktik dilakukan secara berkelompok antara 56 orang untuk setiap obyek; (3) waktu praktik menyesuaikan jam praktik yang telah ditetapkan sekolah; dan (4) tidak melibatkan unit produksi. Kompetensi yang dihasilkan melalui proses yaitu siswa mampu melaksanakan praktik dengan benar sesuai dengan job sheet yang telah ditetapkan. Penilaian pada pembelajaran praktik dilaksanakan dengan melaksanakan observasi atau ujian praktik, proses ini dilakukan dengan tujuan mengetahui sejauh mana siswa mampu melakukan praktek dengan benar dan sesuai prosedur.

Berdasarkan proses yang telah dilaksanakan diperoleh beberapa kelemahan yang dimiliki SMK Karsa Mulya Palangka Raya dalam proses praktikum. Kelemahan yang dimaksud yaitu: (1) Model pembelajaran praktik yang dilaksanakan di SMK Karsa Mulya Palangka Raya tersebut murni memanfaatkan bengkel sebagai sarana praktik tanpa melibatkan fungsi bengkel sebagai unit produksi; (2) dalam proses pembelajaran praktik kegiatan persiapan cenderung dilaksanakan oleh guru dan instruktur sedangkan siswa hanya berperan dalam pelaksanaan proses pembelajaran saja; (3) pelaksanaan proses pembelajaran yang dilakukan yaitu menggunakan sistem training objek, dimana dalam proses pembelajaran tersebut siswa dibagi kedalam beberapa kelompok adapun masing-masing kelompok terdiri atas 5-6 orang setiap objek; (4) proses pembelajaran praktik juga dilakukan penilaian dimana penilaian tersebut dilaksanakan dengan melak-sanakan observasi atau ujian praktik, proses ini dilakukan dengan tujuan kompetensi yaitu sejauh mana siswa hanya mampu melakukan praktek dengan benar dan sesuai prosedur; (5) dalam proses pembelajaran praktik siswa hanya diajarkan berdasarkan modul yang telah 
ditentukan; dan (6) siswa tidak dilibatkan dalam menjalankan unit produksi sekolah sehingga siswa tidak mendapatkan kesempatan untuk belajar meningkatkan jiwa kewirausahaan. Pen- jelasan mengenai pelaksanaan model pembelajaran yang dilakukan di bengkel tersebut dapat dilihat pada Gambar 2.

\begin{tabular}{|c|c|}
\hline \multicolumn{2}{|l|}{ Bengkel otomotif SMK Karsa Mulya } \\
\hline Tempat pembelajaran praktik & \\
\hline 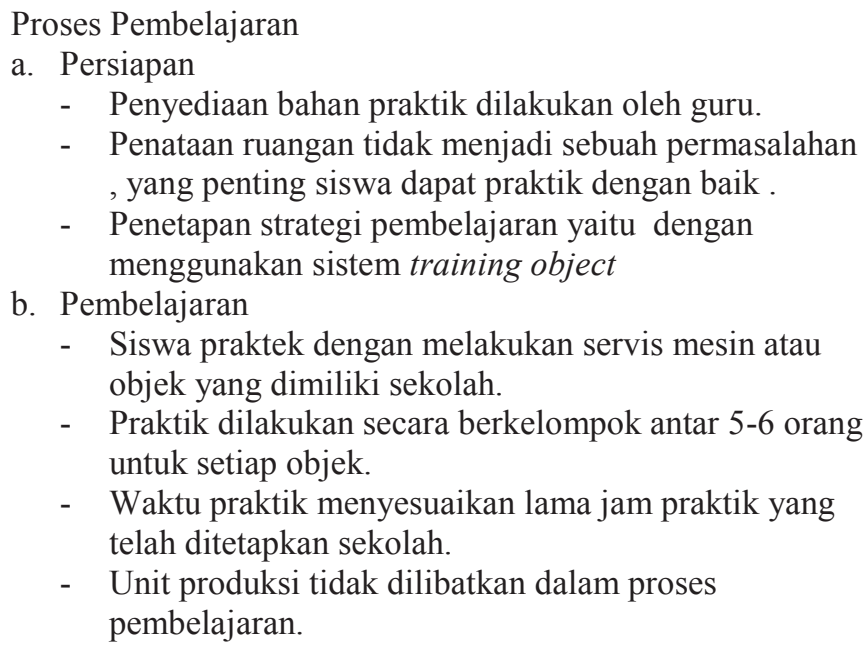 & \multirow{3}{*}{$\begin{array}{l}\text { Kelemahan model : } \\
\text { a. Model pembelajaran praktik tidak } \\
\text { memanfaatkan fungsi bengkel sebagai } \\
\text { unit produksi. } \\
\text { b. Proses pembelajaran praktik kegiatan } \\
\text { persiapan dilaksanakan oleh guru dan } \\
\text { instruktur sedangkan siswa hanya } \\
\text { berperan dalam pelaksanaan proses } \\
\text { pembelajaran saja. } \\
\text { c. pelaksanaan proses pembelajaran } \\
\text { yang dilakukan yaitu menggunakan } \\
\text { sistem training objek yang dimiliki } \\
\text { sekolah. } \\
\text { d. proses penilaian dilakukan dengan } \\
\text { tujuan kompetensi yaitu sejauh mana } \\
\text { siswa mampu melakukan praktek } \\
\text { dengan benar dan sesuai prosedur. } \\
\text { e. dalam siswa hanya diajarkan } \\
\text { berdasarkan modul yang telah } \\
\text { ditentukan. } \\
\text { f. } \text { siswa tidak dilibatkan dalam } \\
\text { menjalankan unit produksi. }\end{array}$} \\
\hline Evaluasi berdasarkan kompetensi yang dimiliki siswa & \\
\hline $\begin{array}{l}\text { Nilai praktik: Nilai yang diperoleh sebatas siswa mampu } \\
\text { melaksanakan praktek dengan benar sesuai prosedur }\end{array}$ & \\
\hline
\end{tabular}

Gambar 2. Model praktik SMK Karsa Mulya (non-teaching factory)

Gambar 2 menunjukkan model pelaksanaan pembelajaran praktik di bengkel Otomotif SMK Karsa Mulya yang digunakan bukan termasuk dalam model teaching factory. Hal tersebut ditandai dengan adanya pemisahan fungsi bengkel sebagai unit produksi dan tempat pembelajaran praktik. Dalam Gambar 2 dapat diketahui bahwa masih ditemui beberapa kelemahan pelaksanaan pembelajaran praktik saat ini. Dengan demikian pengembangan model teaching factory dapat dilaksanakan dengan melakukan beberapa perubahan. Perubahan yang dilakukan hanya dilakukan dalam batasan penyusunan dan pengelolaan sarana dan prasarana serta penyusunan pelaksanaan praktik dengan model teaching factory tidak sampai melakukan perubahan dalam bentuk fisik bangunan. Tujuan sekolah untuk mendirikan sebuah bengkel sepeda motor juga menjadi acuan dalam pengembangan model teaching factory di bengkel otomotif SMK Karsa Mulya Palangka Raya. Dari berbagai acuan tersebut menunjukkan bahwa terdapat urgensi melakukan perubahan pembelajaran praktik untuk menunjang ketercapaian tujuan belajar di bengkel sepeda motor yang mengadopsi model teaching factory.

Plomp (1997) mendeskripsikan bahwa desain sebagai rencana tertulis atau rencana kerja dengan format titik awal dari tahap ini pemecahan yang akan direalisasikan atau dibuat. Hal ini diakhiri dengan kegiatan konstruksi atau 
produksi seperti pengembangan kurikulum atau produksi materi audio-visual. Beberapa hal yang perlu dirancang terkait temuan di investigasi awal, yaitu: (1) merumuskan tujuan produk; (2) sasaran produk; dan (3) deskripsi komponen produk dan penggunaannya. Tujuan produk yaitu mendapatkan sebuah model teahing factory dalam pengelolaan sarana dan prasarana serta pembelajaran praktik di bengkel otomotif yang baik dan sesuai untuk meningkatkan hasil praktik di bengkel otomotif SMK Karsa Mulya Palangka Raya. Sasaran produk pada tahap uji coba adalah SMK yang dipilih dan ditunjuk dengan berbagai pertimbangan yang memenuhi persyaratan untuk melakukan uji coba. Sasaran produk setelah uji coba (setelah model jadi) adalah para pengelola SMK yang sejenis baik di tingkat sekolah negeri maupun swasta serta di tingkat pemerintah daerah atau pusat sebagai bahan pertimbangan dalam memajukan perbaikan SMK di masa depan. Deskripsi Komponen Produk yaitu produk yang diharapkan adalah model teaching factory yang ideal dan cocok digunakan di bengkel otomotif SMK Karsa Mulya Palangka Raya. Dalam pembelajaran praktik yang mengadopsi teaching factory secara langsung melibatkan dan menjalankan unit produksi. Komponen produk yang diharapkan adalah meliputi: (1) pengelolaan sarana dan prasarana, kegunaanya sebagai pedoman dalam pengelolaan sarana dan prasarana yang baik sesuai dengan proses dan kondisi pembelajaran praktek yang dilaksanakan, menyangkut proses penataan, proses peminjaman alat serta proses penggunaan alat; dan (2) pengelolaan pembelajaran praktik (proses pembelajaran di bengkel) kegunaanya sebagai pedoman dalam pelaksanaan pembelajaran praktik.

Tahapan realisasi/konstruk adalah tahapan pengembangan model pembelajaran praktik dengan mengadopsi model teaching factory. Secara umum tahapan tersebut memfungsikan peran bengkel sebagai unit produksi dan tempat belajar praktik, serta menggunakan tahapan pembelajaran yang terstruktur (analisis pada persiapan, penerapan model, bentuk kegiatan pengembangan, proses pembelalajaran, produk, evaluasi dan nilai praktik). Dengan model yang telah dirancang diharapkan didapatkannya model teahing factory dalam pengelolaan sarana dan prasarana serta pembelajaran praktik di bengkel otomotif yang baik dan sesuai berfungsi untuk meningkatkan hasil praktik di bengkel otomotif SMK Karsa Mulya Palangka Raya dan mampu melibatkan peran bengkel sebagai unit produksi.

Proses pembelajaran dilakukan dalam dua bagian yaitu persiapan dan pembelajaran. Persiapan yang dilakukan yaitu: (1) pengelolaan sarana dan prasarana; (2) pengelolaan ruangan; dan (3) penentuan strategi dan sistem yang digunakan dalam proses pembelajaran praktik. Pengelolaan ruangan disesuaikan dengan bentuk bangunan yang telah dimiliki sekolah tanpa merubah bentuk fisik dari bangunan tersebut. Penataan ruangan disusun secara rapi baik itu ruang kerja, ruang tunggu, ruang kepala bengkel, ruang guru, ruang alat dan bahan, serta sarana penunjang lainya. Penyusunan sarana dan prasarana berupa alat-alat dan bahan praktik disusun rapi berdasarkan fungsi, sehingga mempermudah dalam pengontrolan, mempermudah dalam menjangkau dan mempermudah penentuan alat-alat dan bahan yang akan digunakan pada saat praktik.

Dalam pelaksanaan proses pembelajaran model teaching factory terdapat beberapa bagian khusus yang membedakan dengan model praktik non teaching factory yang diterapkan di SMK Karsa Mulya Palangka Raya yaitu: (1) siswa melakukan pekerjaan real sesuai SOP seperti di dunia industri; (2) bahan praktik yang dikerjakan yaitu benda riil atau kendaraan milik konsumen; (3) job kerja berdasarkan permasalahan yang terdapat pada kendaraan konsumen; (4) pekerjaan berdasarkan standar kerja didukung dengan manual servis jenis kendaraan yang dikerjakan; (5) siswa dituntut bekerja berdasarkan waktu sama seperti waktu kerja di dunia industri; (6) keselamatan kerja lebih ditingkatkan baik alat, orang dan benda kerja; dan (7) penanaman rasa tanggung jawab lebih besar terutama terhadap kepuasan konsumen. Proses pelaksanaan pembelajaran praktik bertujuan 
menghasilkan sebuah produk yang berupa jasa servis sepeda motor. Berdasarkan produk yang dihasilkan tersebut maka guru atau instruktur dapat melakukan penilaian terhadap kompetensi yang dimiliki siswa dengan melakukan observasi langsung terhadap proses praktik yang dilakukan oleh siswa dan hasil pekerjaan siswa tersebut. Pencapaian yang diharapkan yaitu siswa memiliki kompetensi yang tidak hanya mampu melaksanakan praktik sesuai dengan SOP saja melainkan siswa juga memiliki kompetensi, pengalaman, dan kemampuan menyelesaikan masalah terhadap motor yang diservis tepat waktu karena hasil kerja tersebut menjadi poin terbesar bagi siswa dalam memperoleh nilai praktik. Secara mendetail mengenai model pembelajaran teaching factory di SMK Karsa Mulya dapat dilihat dalam Gambar 3.

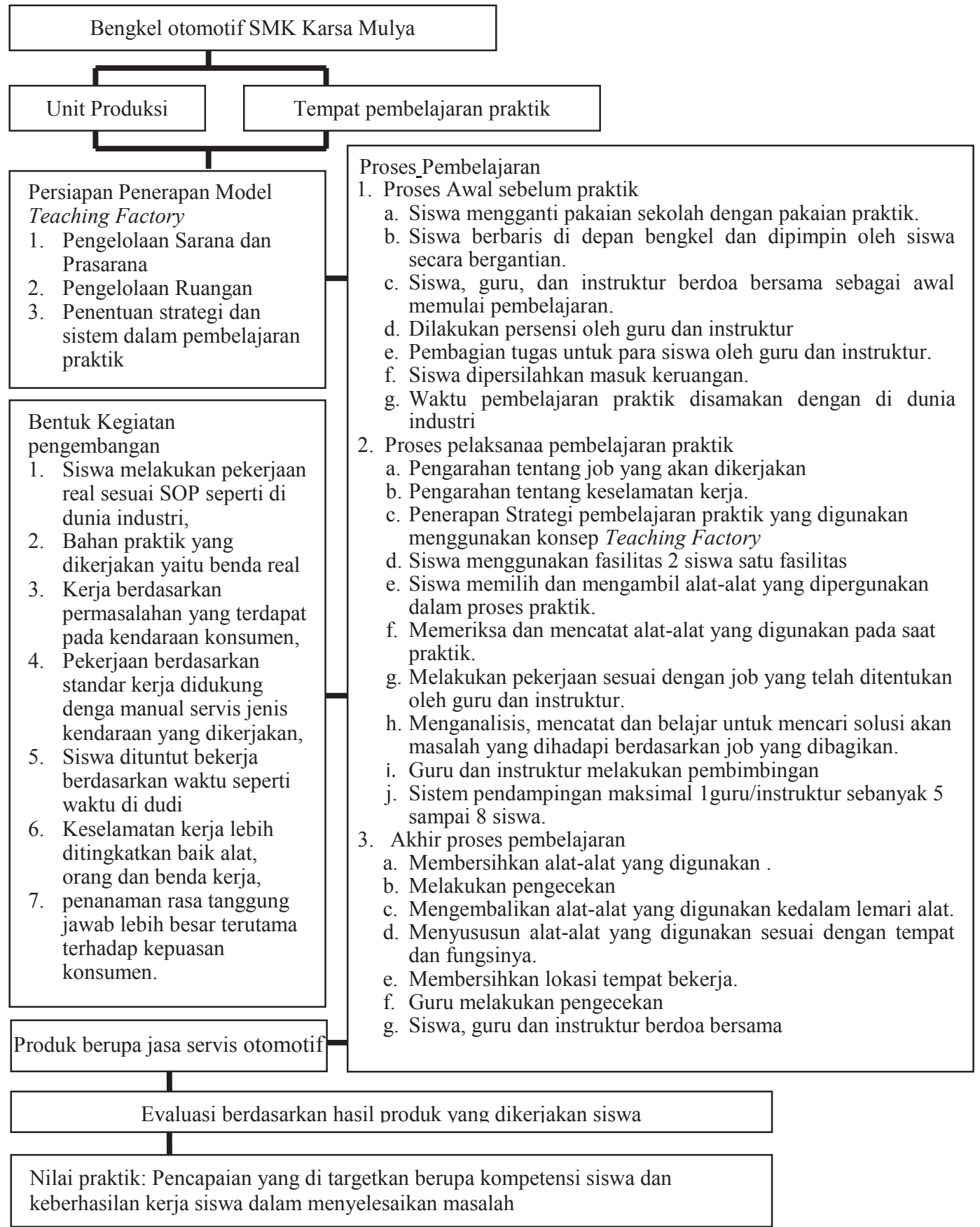

Gambar 3. Model Teaching factory di SMK Karsa Mulya 
Gambar 3 memperlihatkan konstruksi model teaching factory tidak lagi memisahkan dua fungsi bengkel. Tahapan konstruksi pada intinya mengkonstruksi model pembelajaran praktik berbasis model teaching factory yang sesuai di bengkel otomotif SMK Karsa Mulya. Setelah konstruksi dilakukan dan dikonsultasikan kepada expert, maka selanjutnya dilakukan tahapan tes, evaluasi dan revisi. Suatu pemecahan yang dikembangkan harus diuji dan dievaluasi dalam praktik. Evaluasi yaitu sebuah proses yang dilakukan untuk memperoleh data informasi yang dibutuhkan dalam mengambil keputusan menyangkut proses maupun produk yang dihasilkan dalam suatu kegiatan (Stark dan Thomas, 1994; Stufflebeam dan Shinkfield, 1985). Evaluasi dilakukan berdasarkan proses pengembangan yang dilakukan, produk yang dihasilkan. Evaluasi sebagai proses pengumpulan, pemrosesan dan penganalisaan informasi secara sistematik, untuk memperoleh nilai realisasi dari pemecahan. Dengan kata lain, apakah situasi yang diinginkan sudah sesuai sebagaimana yang diuraikan pada perumusan masalah. Sehingga dengan data yang didapatkan melalui penelitian diketahui bagian atau masalah mana yang sudah sesuai dan bagian mana yang masih diperlukan pengembangan. Kegiatan ini biasa disebut siklus balik. Siklus diulang sampai pemecahan yang diinginkan tercapai.

Hasil observasi proses pembelajaran, menunjukkan kegiatan berupa: (1) siswa berbaris di depan bengkel dengan berpakaian kerja lengkap, dilakukanya persensi dan doa pembuka, pembagian tugas yang dilakukan oleh guru/instruktur, kegiatan ini dilakukan rutin setiap 5 menit sebelum proses praktik dilaksanakan; (2) pengarahan tentang job yang akan dikerjakan pada saat praktik oleh guru dan instruktur dan pengarahan tentang keselamatan kerja berjalan dengan baik dan dilaksanakan rutin selama penelitian dilaksanakan; (3) penerapan strategi pembelajaran praktik menggunakan konsep teaching factory dapat berjalan dengan baik terlihat dari proses praktik yang dilaksanakan yaitu menyesuaikan dengan SOP yang dimiliki oleh dunia industri dan disesuaikan dengan kurikulum yang sudah disusun oleh sekolah serta beberapa teknik yang dilaksanakan juga mengikuti teknik yang dilaksanakan di dunia industri; (4) dalam proses praktikum yang semula ditargetkan 2 siswa praktik menggunakan 1 fasilitas namun pada saat penelitian dilaksanakan dan melalui diskusi dengan guru dan instruktur praktik maka disusun sebuah jadwal praktik sehingga pada saat praktik hanya dilaksanakan oleh 4 orang siswa maka masingmasing siswa dapat menggunakan 1 fasilitas secara penuh; (5) siswa diberikan kepercayaan penuh terhadap fasilitas yang digunakan dalam proses pembelajaran praktik hal tersebut merupakan upaya untuk menanamkan rasa tanggung jawab siswa, melatih kejujuran siswa dan memberikan hak kebebasan pada siswa untuk bekerja tanpa terbeban dengan rasa takut; (6) siswa dianjurkan untuk selalu melakukan perkerjaan dengan cara menganalisis dan mencatat masalah apa yang sedang dihadapi serta mencari solusi apa yang harus dilakukan teknik ini berjalan dengan baik; (7) job yang dikerjakan oleh siswa yaitu melakukan servis sepeda motor yang terdiri dari tune up, overhaul dan sistem kelistrikan, sepeda motor yang dikerjakan tersebut terbuka bagi siapa saja seperti sepeda motor milik bapak/ibu guru SMK Karsa Mulya, seluruh siswa dan terbuka bagi masyarakat umum yang sudah mengetahui keberadaan bengkel sekolah SMK Karsa Mulya; (8) proses pendamping yang dilakukan oleh guru praktik juga berjalan dengan baik berhubung dalam sehari hanya terdiri dari 4 siswa yang melakukan praktik maka guru dapat dengan mudah untuk mengontol setiap kegiatan yang dilakukan siswa selama melakukan praktik, (9) akhir proses kegiatan praktikum siswa membersihkan alat-alat yang digunakan, melakukan pengecekan fasilitas yang digunakan, menyusun kembali alat-alat tersebut kembali ketempat semula sama seperti sebelum praktik dilaksanakan; (10) siswa melakukan pembersihan ruangan tempat praktik setiap proses praktik berakhir dan dilakukan rutin, (11) guru melakukan pengecekan atas fasilitas yang sudah digunakan pada saat praktik, dan (12) untuk 
akhir kegiatan prktikum semua dilakukan dalam waktu 15 menit setelah praktik dilakukan dan sebelum pulang selalu dilakukan doa penutup.

Pada tahapan implementasi dilaksanakan dengan memperhatikan situasi dan kondisi yang ada dan terjadi di lapangan. Setelah dilakukan evaluasi dan diperoleh produk hasil, maka produk dapat dimplementasikan pada wilayah yang lebih luas. Plomp. (1997) menyatakan bahwa pemecahan masalah harus dikenalkan, dengan kata lain, model teaching factory dalam pembelajaran praktik sebagai solusi pemecahan masalah harus diimplementasikan. Berdasarkan produk yang dihasilkan, evaluasi dilakukan dengan melakukan observasi langsung proses praktik. Setelah siswa selesai melakukan praktik dengan memperhatikan tahap-tahap dalam proses kerja yang dilakukan siswa serta keberhasilan kerja siswa dalam memecahkan masalah yang terjadi pada jenis sepeda motor yang diservis sesuai dengan waktu kerja seperti yang dilaksanakan di dunia industri pada umumnya, maka dapat diketahui sejauh mana tingkat kompetensi yang dimiliki siswa dalam belajar melaksanakan servis secara nyata, melakukan analisis, melakukan servis dan menentukan solusi terhadap masalah yang dihadapi sehingga memperoleh hasil kerja yang baik. Dikarenakan jenis produk yang dihasilkan berupa jasa servis sepeda motor maka hasil kerja atau servis yang dilakukan sangat berpengaruh terhadap kepuasan konsumen sehingga siswa dituntut benarbenar sabar dan teliti dalam melakukan servis. Keberhasilan siswa dalam melaksanakan servis sepeda motor secara langsung otomatis menjadi modal awal siswa dalam mempersiapkan diri sebagai mekanik profesional setelah lulus dari SMK.

Berdasarkan data hasil observasi langsung terhadap proses pengembangan yang dilakukan dapat disimpulkan bahwa proses pengembangan yang dilakukan telah berjalan dengan baik, akan tetapi terdapat beberapa proses yang tidak terlaksana sehingga diperlukan adanya revisi terhadap model yang telah disusun sebelumnya sehingga diperoleh sebuah model praktik yang cocok dilaksanakan di SMK Karsa Mulya Palangka Raya dengan keterbatasan yang dimiliki oleh pihak sekolah.

Tabel 1 merupakan data hasil praktik Tune Up, Over Haul, dan starter system yang diperoleh siswa SMK Karsa Mulya Jurusan Teknik Sepeda Motor Kelas XI yang berjumlah 19 orang selama melakukan praktik menggunakan konsep teaching factory.

Tabel 1. Data Nilai Hasil Praktik

\begin{tabular}{ccccccccccc}
\hline \multirow{2}{*}{ No } & $\begin{array}{l}\text { Materi } \\
\text { praktik }\end{array}$ & $\begin{array}{c}\text { Persi- } \\
\text { apan }\end{array}$ & $\begin{array}{c}\text { Proses } \\
\text { kerja }\end{array}$ & $\begin{array}{c}\text { Hasil } \\
\text { kerja }\end{array}$ & $\begin{array}{c}\text { Sikap } \\
\text { kerja }\end{array}$ & Waktu & $\begin{array}{c}\text { Skor } \\
\text { total }\end{array}$ & Nilai & $\begin{array}{c}\text { Nilai } \\
\text { tertinggi }\end{array}$ & $\begin{array}{c}\text { Nilai } \\
\text { terendah }\end{array}$ \\
\hline 1 & $\begin{array}{l}\text { Tune } \\
\text { Up }\end{array}$ & 4,93 & 4,59 & 4,53 & 4,99 & 5,00 & 80,95 & 95,23 & 98,82 & 89,41 \\
2 & $\begin{array}{l}\text { Over } \\
\text { Haul }\end{array}$ & 4,33 & 4,43 & 5,00 & 3,89 & 4,00 & 64,16 & 85,55 & 90,67 & 82,67 \\
& $\begin{array}{l}\text { Starter } \\
\text { System }\end{array}$ & 4,35 & 3,41 & 4,95 & 4,00 & 4,00 & 58,47 & 78,00 & 80,00 & 77,33 \\
\hline
\end{tabular}

Berdasarkan hasil perolehan nilai praktik pada saat praktik menggunakan model teaching factory di SMK Karsa Mulya Palangka Raya yang ditampilkan melalui Tabel 1 menggambarkan bahwa nilai kompetensi siswa berada pada tingkat kategori baik. Dengan melihat nilai tiap mahasiswa, pada setiap sub komponen tes, siswa memperoleh nilai pada skor 3-5 dan tidak terdapat siswa yang memperoleh skor 0-2. Sehingga jika dimasukkan berdasarkan kriteria perhitungan nilai praktik maka nilai tertinggi dan terendah yang diperoleh siswa berada dalam kategori nilai yang baik (diatas 75).

Melalui observasi langsung terhadap proses praktikum yang dilaksanakan dapat dikatakan berjalan dengan baik. Skor yang 
ditetapkan dari masing-masing komponen yaitu berada pada rentang (0-5) jadi skor maksimal yang diperoleh siswa yaitu 5 dan skor terendah yaitu 0. Adapun perolehan nilai praktik dari masing-masing kompetensi yaitu: (a) nilai yang diperoleh siswa pada kompetensi Tune Up yaitu skor nilai tertinggi $=98,82$; nilai terendah $=$ 89,41 ; dan nilai rata-rata $=95,23$; (b) nilai yang diperoleh siswa pada kompetensi Over Haul yaitu skor nilai tertinggi $=90,67$; nilai teren$\mathrm{dah}=(82,67$; dan nilai rata-rata $=85,54$; serta $(\mathrm{c})$ nilai yang diperoleh siswa pada kompetensi system starter yaitu skor nilai tertinggi $=80,00$; nilai terendah $=77,33$; dan nilai rata-rata $=77,96$. Dari hasil perolehan nilai tersebut dapat disimpulkan bahwa pembelajaran praktik dengan model teaching factory dapat dilaksanakan di bengkel otomotif SMK Karsa Mulya dan secara nyata mampu membuat siswa mencapai kompetensi yang baik yang dibuktikan dengan perolehan nilai diatas 75 .
Berdasarkan hasil proses pengembangan yang dilakukan mulai dari proses persiapan, proses praktik dan proses evaluasi yang dilaksanakan jelas bahwa proses pengembangan telah berjalan dengan baik serta tujuan pengembangan yang dilakukan tercapai dengan baik. Pengembangan proses persiapan, proses praktik dan proses evaluasi yang telah dilaksanakan kemudian ditelaah dan direvisi. Hal yang direvisi meliputi: (1) pengelolaan sarana dan prasarana; (2) waktu pelaksanaan praktik; dan (3) pemanfaatan sarana dalam proses praktik terkait pembagian jumlah kelompok dan jadwal praktik. Dibutuhkan pengelolaan sarana dan prasarana kebutuhan praktikum yang lebih optimal. hal tersebut agar mudah dijangkau oleh siswa saat membutuhkan alat dan bahan praktik. Gambar 4 berikut ini menunjukkan pengelolaan ruangan dengan model teaching factory.

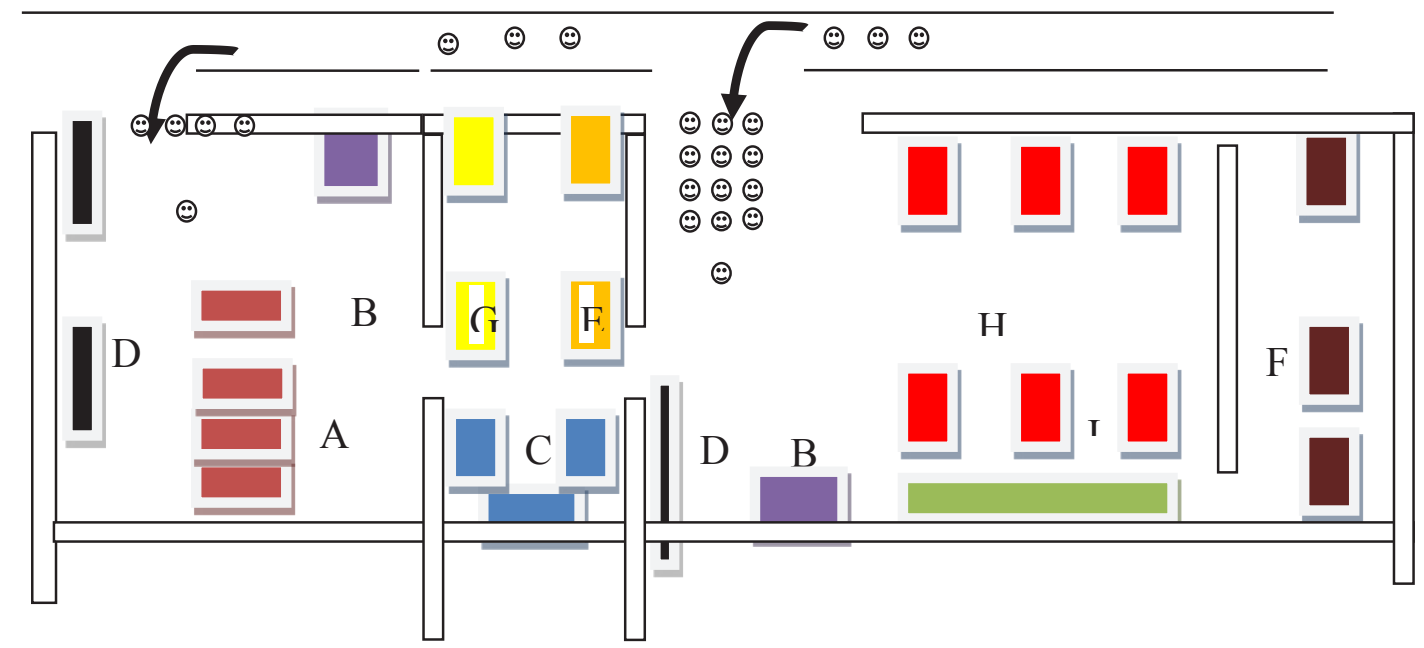

Keterangan:

A: Bahan Praktik

B: Meja guru

C: Ruang kepala bengkel, guru instruktur

D: Kursi tunggu pelanggan

E: Lemari alat TKR

F: Ruang Kelistrikan

G: Lemari alat dan bahan TSM

H: Meja Kerja TKR

I: Meja kerja bangku

(:): siswa dan guru/instruktur
1. Aspek aspek keselamatan kerja dan petunjuk kerja di tempel di sisi dinding ruangan.

2. Jalur proses dan strategi yang dikembangkan semua dilaksanakan di dalam bengkel dan sekitar halaman bengkel

3. Akses jalur menuju ruang bengkel mengikuti arah panah.

4. Jenis proses yang dilaksanakan diterangkan pada tabel model pengembangan yang dibuat.

Gambar 4. Bengkel Otomotif SMK Karsa Mulya Model Teaching factory

Gambar 4 menunjukkan pengelolaan sarana dan prasarana yang terlihat telah memperhitungkan aspek K3 dan memudahkan siswa menjangkau alat dan bahan praktik. Dari hasil penelaahan dan revisi, maka diperoleh model pembelajaran praktik yang mengadopsi teaching factory dalam pengelolaan sarana dan prasarana praktik serta proses pelaksanaan pembelajaran praktik di bengkel otomotif SMK 
Karsa Mulya Palangka Raya, seperti Gambar 5 berikut ini.

\section{Persiapan Penerapan Model Teaching Factory}

1. Pengelolaan Sarana dan Prasarana

(a) melakukan proses penataan alat-alat yang dimiliki disesuaikan dengan fungsi, jenis dan kondisi alat; (b) menyusun tempat kedudukan mesin atau objek yang akan dijadikan job dalam pekerjaan; (c) membuat sebuah sistem dalam pendistribusian alat-alat yang digunakan; (d) menyusun jadwal maintenance secara berkala; dan (e) melakukan penyiapan alat-alat sebelum proses pembelajaran dilakukan

2. Pengelolaan Ruangan

(a) penataan ruangan bengkel menyerupai bengkel kerja di dunia industri; (b) menyusun sarana yang ada berdasarkan job-job pekerjaan yang dilakukan (kerja bangku, kelistrikan, servis engine) pengkondisian rungan yang nyaman untuk bekerja; (c) penyusunan ruangan berdasarkan masing-masing fungsi (ruang alat, ruang guru/instruktur, ruang tunggu, dan ruang kerja); (d) penataan ruangan sesuai dengan fungsi, jenis kerja untuk jurusan TSM; (e) menjaga kondisi ruangan agar tetap bersih dengan terus melakukan; (f) menyusun tanda-tanda peringatan tentang $\mathrm{K} 3$; dan (g) menyusun pemasangan poster atau gambar prosedur kerja sesuai dengan lokasi kerja yang dilakukan

3. Penentuan strategi dan sistem dalam pembelajaran praktik

(a) pemilihan strategi pembelajaran oleh guru; (b) penerapan Strategi pembelajaran praktik yang mengguna-kan konsep Teaching Factory artinya kompetensi yang ditanamkan berpedoman pada pencapaiaan kompetensi terhadap jenis job yang telah ditetapkan sebelumnya proses pekerjaan atau pembelajaran praktik dilakukan serta disesuaikan dengan kurikulum yang telah ditetapkan. Strategi berbasis produksi disesuaikan dengan job yang ada dan permintaan dalam unit produksi; (c) sistem yang dignakan yaitu system blok dengan alasan penanaman kompetensi akan sangat mudah tercapai jika proses kerja yang dilakukan tidak terputus-putus namun dibagi dalam beberapa kelompok 1 kelompok 4 orang; (d) memanfaatkan unit produksi sebagai penunjang pelaksanaan Teaching Factory.

\section{Proses Pembelajaran}

1. Proses Awal sebelum praktik

(a) siswa dipersilahkan untuk mengganti pakaian sekolah dengan pakaian praktik; (b) siswa berbaris di depan bengkel dan dipimpin oleh siswa secara bergantian; (c) siswa, guru, dan instruktur berdoa bersama sebagai awal memulai pembelajaran; (d) dilakukan persensi oleh guru dan instruktur; (e) pembagian tugas untuk para siswa oleh guru dan instruktur; (f) siswa dipersilahkan masuk keruangan; dan(g) waktu pembelajaran praktik disamakan dengan waktu kerja di dunia industri yaitu 1 jam $=60$ menit dimulai jam 07.00 sampai 14.00 WIB.Proses ini dilakukan 5 menit sebelum pembelajaran dilakukan.

2. Proses pelaksanaan pembelajaran praktik

(a) pengarahan tentang job yang akan dikerjakan pada saat praktik oleh guru dan instruktur; (b) pengarahan tentang keselamatan kerja; (c) penerapan Strategi pembelajaran praktik yang digunakan menggunakan konsep Teaching Factory artinya kompetensi yang ditanamkan berpedoman pada pencapaiaan kompetensi terhadap jenis job yang telah ditetapkan sebelumnya proses pekerjaan atau pembelajaran praktik yang dilakukan serta disesuaikan dengan kurikulum yang telah ditetapkan; (d) siswa menggunakan fasilitas 1 siswa satu fasilitas hal ini dilakukan karena hanya 4 siswa praktik setiap harinya; (e) siswa dipersilahkan menuju ruang alat untuk memilih dan mengambil alat-alat yang dipergunakan dalam proses praktik; (f) memeriksa dan mencatat alat-alat yang digunakan pada saat praktik; (g) melakukan pekerjaan sesuai dengan job yang telah ditentukan oleh guru dan instruktur; (h) menganalisis, mencatat dan belajar untuk mencari solusi akan masalah yang dihadapi berdasarkan job yang dibagikan; (i) guru dan instruktur melakukan pembimbingan dan memantau proses yang dilakukan siswa; dan (j) sistem pendampingan dilaksanakan secara penuh dikarenakan siswa yang praktik hanya 4 siswa perharinya sehingga proses pendampingan pun sedikit lebih mudah dan maksimal. Proses ini dilakukan sesuai dengan waktu pembelajaran praktik yang telah ditetapkan

3. Akhir proses pembelajaran

(a) membersihkan alat-alat yang digunakan; (b) melakukan pengecekan jumlah dan jenis alat yang telah dipergunakan pada saat praktik; (c) mengembalikan alat-alat yang digunakan kedalam lemari alat; (d) penyususun alat-alat yang digunakan sesuai dengan tempat dan fungsinya; (e) seluruh siswa bersama-sama membersihkan lokasi tempat bekerja agar selalu bersih dan bebas dari bahaya; (f) guru melakukan pengecekan; dan (g) siswa, guru dan instruktur berdoa bersama untuk mengakhiri proses pembelajaran praktik.Proses tersebut dilakukan 15 menit setelah proses pembelajaran praktik dilakukan.

\section{Produk berupa Jasa servis otomotif}

Evaluasi: .(1) tes ujian praktik; (2) tes tertulis; (3) penilaian proses pelaksanaan praktikum melalui pengamatan langsung; dan (4) hasil kerja siswa atau produk.

Uji kompetensi yang digunakan yaitu berpedoman pada uii kompetensi yang ditetapkan oleh Direktorat PSMK.

Gambar 5. Model teaching factory di SMK Karsa Mulya 
Secara umum dapat diketahui dari Gambar 5, bahwa pembelajaran praktik model teaching factory yang dilaksanakan di bengkel Otomotif SMK Karsa Mulya terdiri dari: (1) persiapan berupa: (a) pengelolaan sarana dan prasarana; (b) pengelolaan ruangan; dan (c) penentuan strategi dan sistem dalam pembelajaran praktik.; (2) proses pembelajaran berupa: (a) proses awal sebelum praktik; (b) proses pelaksanaan pembelajaran praktik; dan (c) akhir proses pembelajaran.; dan (3) Evaluasi berupa: (a) tes ujian praktik; (b) tes tertulis; (c) penilaian proses pelaksanaan praktikum melalui pengamatan langsung; dan (d) hasil kerja siswa atau produk. Dengan melaksanakan tahapan pembelajaran tersebut, pencapaian kompetensi siswa berupa hasil produk yang dikerjakan siswa sesuai permintaan pelanggan dapat terpenuhi. Nilai praktik merupakan pencapaian kompetensi siswa dan keberhasilan kerja siswa dalam menyelesaikan masalah.

\section{SIMPULAN}

Simpulan yang dapat ditarik berdasarkan analisis data dan kajian terhadap hasil pengembangan secara umum menunjukkan bahwa model teaching factory yang dikembangkan sudah sesuai dengan criteria yang dipersyaratkan yaitu: (1) tersedianya ruangan sebagai tempat pelaksanaan praktik; (2) Terdapat unit produksi sebagai tempat pelaksanaan proses; (3) tersedia saranan dan prasarana penunjang seperti Alat-alat, kunci-kunci, dan mesin; (4) telah memanfaatkan kondisi lingkungan setem-pat dalam proses pembelajaran praktik; (5) sumber daya manusia yang terlibat di dalam pelaksanaan yaitu guru/instruktur dan siswa; (6) adanya kerjasama antara pihak industri dan pihak sekolah; (7) guru mata pelajaran praktik, instruktur memiliki komitmen dalam melaksanakan dan menerapkan konsep pembelajaran praktik model teaching factory; dan (8) siswa terlibat penuh dalam proses. Efektivitas terhadap proses pengembangan model teaching factory yang dilaksanakan ditunjukkan dengan kemampuan siswa dalam menyelesaikan pekerjaan dengan cepat, baik dan benar serta hasil uji kompetensi terhadap proses pembelajaran yang telah dilaksanakan selama praktik dengan menerapkan model Teaching factory serta melalui pengamatan langsung informasi terhadap keberadaan bengkel otomotif SMK Karsa Mulya mulai meluas dan minat konsumen lebih meninggkat. Berdasarkan hasil uji kompetensi yang dilakukan menunjukan bahwa dari 19 orang siswa jurusan teknik sepeda motor, nilai praktik yang diperoleh siswa berdasarkan kriteria penilaian praktik kejuruan yaitu rata-rata berada pada tingkatan baik. Hal tersebut ditunjukan dengan perolehan skor terendah sebesar 3 dan skor tertinggi sebesar 5 pada rentang (0-5). Adapun perolehan nilai praktik dari masing-masing kompetensi yaitu: (a) nilai yang diperoleh siswa untuk kompetensi tune up yaitu skor nilai tertinggi sebesar 98,82 dan nilai terendah sebesar 89,41 sedangkan nilai rata-rata sebesar 95,23, (b) nilai yang diperoleh siswa untuk kompetensi over haul yaitu skor nilai tertinggi sebesar 90,67 dan nilai terendah sebesar 82,67 sedangkan nilai rata-rata sebesar 85,55, (c) nilai yang diperoleh siswa untuk kompetensi sistem starter yaitu skor nilai tertinggi sebesar 80,00 dan nilai terendah sebesar 77,33 sedangkan nilai rata-rata sebesa 78,00 . Dengan demikian jelas bahwa model teaching factory dapat digunakan dan diterapkan pada bengkel Kejuruan jurusan Teknik Sepeda Motor SMK Karsa Mulya Palangka Raya.

\section{DAFTAR RUJUKAN}

Alptekin, S.E. et al. 2001. Teaching factory. Proceedings of the 2001 American Society for Engineering Education Annual Conference \& Exposition, San Luis Obispo, 3563

Badan Pengembangan dan Pembinaan Bahasa. 1995. Kamus besar bahasa Indonesia. Jakarta: Balai Pustaka

Clarke, L., and Winch, C. 2007. Vocational Education: Internasional Approaches, Developments, and System. New York: Routledge 
Dikmenjur. 1996 Pedoman Teknik Pelaksanaan Pendidikan System Ganda pada SMK, Depdikbud: Jakarta

Direktorat PSMK. 2006. Penyelenggaraan Sekolah Menengah Kejuruan Kaitanya dengan Aspek Mutu Outcome Standar Nasional Pendidikan (SNP). Jakarta: Depdiknas

Direktorat PSMK. 2008. Roadmap Pengembangan SMK 2010-2014. Jakarta: Departemen Pendidikan Nasional

Edward V.W and Andrew D.A. 1976. Modern School Shop Planning Seventh Edition, Michigan: Prakken Pub,inc

Finch, C. R and Crunkilton. John. 1999. Curriculum Development in Vocational and Technical Education: Planning, Content, and Implementation. Needham Heights, MA: Allyn \& Bacon. Inc

Forester, W.J. 1973. Industrial Dynamics. Massachusetts, USA: The MIT Press

Hadlock, H. et al. 2008. From Practice to Entrepreneurship: Rethingking the Learning Factory Approach. Proceeding of the 2008 IAJC IJME International Conference, ISBN 978-1-60643-379-9

Hasbullah. 2010. Implementasi Pabrik Pengajaran (Teaching factory) untuk Meningkatkan Kompetensi Siswa SMK: Seminar Internasional, ISSN 1907-2066 Peran LPTK Dalam Pengembangan Pendidikan Vokasi di Indonesia: APTEKINDO

Usman, Husaini. 1998. Kepemimpinan Entrepreneur di Pendidikan Kejuruan, Bandung: Alfabeta

Siswanto Ibnu. 2011. Pelaksanaan Teaching factory di SMK RSBI Daerah Yogyakarta. Tesis Magister. Tidak diterbitkan. Universitas Negeri Yogyakarta: Yogyakarta

Plomp, T. 1997. Educational \& Training system Design: Introduction University of Twen$=t e$. Faculty of Education Science and Technology. Enschede, The Netherlands
Lamancusa, J.S. et al. 2008. The Learning Factory: Industry-Partnered Active Learning. Journal of Engineering Education

Nayang Polytechnic. 2003. Teaching factory Concept. Diambil dari http://www.nyp. edu.sg/seg/innovative-teachingnlearning/ the-teaching-factory-concept pada $14 \mathrm{Fe}$ bruari 2013

Hamalik, Oemar. 2007. Kurikulum dan Pembelajaran. Jakarta: PT. Bumi Aksara

Orlich, D.C. et al. 2007. Teaching Strategies: A Guide to Effective Instruction. New York: Houghton Mifflin Company

School Shop Magazine and The Education Digest. 1982. Modern School Shop Planning. Michigan: Prakken Pub,inc.

Stark, J.S \& Thomas, A. 1994. Assessment and Program Evaluation. Massachusetts: Simon \& Schuster Publishing

Storm, G. 1995. Managing the Occupational Education Laboratory, Michigan: Prakken Publications, inc.

Stufflebeam, D.L. and Shinkfield, A.J. 1985. Systematic Evaluation. Massachusetts: Kluwer-Nijhoff Publishing

Sugihartono. 2009. Kendala yang Dihadapi oleh Pihak Industri dalam Pendidikan Sistem Ganda. Diambil dari http://sugihartono1. wordpress.com/2009/11/04/pendidikan sistem ganda/ pada 14 Februari 2013

Their, Herbert, D. 1970. Teaching Elementary School Science. A Laboratory approach. New York: Heath and Company

Sukardi Thomas. 2008. Pengembangan Model Bengkel Kerja Praktik Sekolah Menengah Kejuruan. Disertasi doctor, tidak diterbitkan, Universitas Negeri Yogyakarta: Yogyakarta 